\title{
A care deficit? The roles of families and faith-based organisations in the lives of youth at the margins in Pretoria Central
}

Author:
Marlize Rabe ${ }^{1}$ -
Affiliation:
'Department of Sociology,
University of South Africa,
South Africa
Corresponding author:
Marlize Rabe,
rabeme@unisa.ac.za
Dates:
Received: 04 Apr. 2018
Accepted: 29 June 2018
Published: 16 Aug. 2018
How to cite this article:
Rabe, M., 2018, 'A care
deficit? The roles of families
and faith-based organisations
in the lives of youth at the
margins in Pretoria Central',
to read online.
HTS Teologiese Studies/
Theological Studies 74(3),
5005. https://doi.
org/10.4102/hts.v74i3.5005
Copyright:
(C) 2018. The Authors.
Licensee: AOSIS. This work
is licensed under the
Creative Commons
Attribution License.

After completing or dropping out of school, many young people leave their family households and in some cases they move from rural or semi-rural areas to urban centres. Faith-based organisations (FBOs) in major cities in South Africa sometimes act as a safety net for marginalised youth, especially as government departments are overburdened and not addressing all the needs of youth at the margins. This qualitative research is based on an analysis of individual and focus group interviews undertaken with young people living in the central areas of Pretoria. It is shown how families and FBOs engage as separate, although at times not unrelated, entities in the lives of youth at the margins. In certain cases, the FBO became an institution of last resort and only in rare cases is a certain synergy achieved between FBOs and families.

\section{Introduction}

This article centres on some of the ways in which faith-based organisations (FBOs) take on caring roles towards youth at the margins in Pretoria Central. Caring for children and young people is usually undertaken by various kin structures, and in African contexts the larger community often shares this responsibility. However, there is also clear evidence in present-day South Africa that when biological parents are not present, the gaps they leave cannot always be filled by other family or community members (Makiwane, Gumede \& Molefi 2016:26). Apart from families and communities, the state also has a role to play in caring for its citizens, including children and the youth. The metaphor of a care diamond, as postulated by Razavi (2011:879), highlights the roles of the state, market, family and communities, including non-profit organisations (NPOs). This care diamond will be considered here to illuminate the different ways in which care from different role players may manifest itself in the lives of individuals. The character of FBOs (as a specific type of NPO) and the ways in which it may relate to caregiving and other caregiving institutions (namely the family and the state) will be given specific attention.

This discussion starts with an outline of the methodology used in the research. In order to reach a greater understanding of the coping mechanisms young people and their families employ, qualitative data is analysed here from one of the case studies in a multisite research project, titled 'Youth at the margins: A comparative study of the contribution of FBOs to social cohesion in South Africa and Nordic Europe' (cf. Swart 2013:2-26). This case study is located in Pretoria Central, which is within the municipal borders of the City of Tshwane in the province of Gauteng, South Africa. The data presented here derive from focus group and individual research interviews with young people living in Pretoria Central. An overview of family structures and dynamics in South Africa is given, after which FBOs are briefly situated within the South African context. Family structures in South Africa are well known for being exceptionally diverse and fluid for specific socio-historical reasons (cf. Budlender \& Lund 2011:926-927; Department of Social Development 2012:11-12; Grieger et al. 2014:146-147; Hall \& Posel 2018:1-20; Spiegel 1996:5-6; Reynolds 2016:253-272). The diversity of family structures is, for example, demonstrated by South Africa still being the only country in the world where both same-sex unions and polygyny ${ }^{1}$ are legally recognised (Rabe 2017:1193). In addition to such family dynamics, poverty and unemployment are affecting the daily lives of many families as is also seen in the research participants of this study. Yet the agency of families as units as well as individual family members are repeatedly demonstrated in qualitative studies (cf. Mosoetsa 2011:23-56; Reynolds 2016:253-272; Wright, Noble \& Ntshongwana 2014:4-51). This analysis aims to add insight into such agency by focusing 1.'Polygyny' refers to one man being married to more than one woman simultaneously and 'polyandry' to one woman being married to
more than one man simultaneously. 'Polygamy' is the umbrella term for these two terms and is used in everyday conversation because polyandry is a scarce phenomenon. 
on the dynamics of caregiving as young people move between state structures, FBOs and families - the interlinking theme of the discussion.

\section{Methodology}

In this study, three types of qualitative interviews formed the basis of the gathered data. Firstly, we $\mathrm{w}^{2}$ (the researchers) held individual interviews with resource people including youth workers, pastors and a school principal. Secondly, we conducted 24 individual interviews with young people, and thirdly we undertook three focus group interviews with young people. Initially, we wanted to include only people older than 15 and younger than 25 years, but valuable information was obtained from three individual interviews with people between the ages of 25 and 30 years; hence these interviews were included in the analysis. We made use of interview guides and audio recorded all interviews with the exception of one participant who did not want the discussion to be audiotaped, and therefore only detailed notes were documented. Because the interviews took place at different locations in the city and usually close to where the participants lived or worked, observation was an added bonus as the fieldwork progressed and occasional field notes were made.

We made use of purposive sampling after identifying five areas from which we could recruit research participants. Various community workers employed by FBOs within these five areas assisted us in finding willing participants. The areas included a community centre and preschool in a small suburb adjacent to the city, a temporary shelter for women, a youth housing project for young women, a food distribution point, a drop-in centre operating during office hours and another operating at night as well. The participants may have made use of the drop-in centres regularly but not necessarily. One focus group was held in the small suburb mentioned above, a second focus group, with only men, was held at a centre in the city, and the third focus group with only women was at a shelter for women.

Ethical clearance for the study was obtained from the University of South Africa prior to the fieldwork. All the research participants were young black ${ }^{3}$ people and some of them were anxiously seeking job opportunities. The researchers, three middle-class white people employed by two separate universities, were easily associated with people who have possible access to opportunities. Despite the information letters outlining the aims of the research and the rights of the research participants, we therefore had to reiterate that participation in the research was voluntary and that participants would not benefit directly from the research. One participant left after this was made clear and the rest of

2.With acknowledgement to my co-researchers and co-fieldworkers Prof. Ignatius Swart and Dr Stephan de Beer.

3.In South Africa the term 'black' is sometimes used to refer to black, coloured (mixed race) and Indian families as these three categories were developed and used by the apartheid government to discriminate against people by (amongst other things) restricting the public spaces they have access to and specifying where they may live, restricting the public spaces they have access to and specifying where they may live,
walk or work (Rabe 2006:23-46). We refer to these four racial categories in this study, as they are still used in official documents in South Africa, to highlight that study, as they are still used in official documents in South Africa, to highlight that black people. the participants were willing to relate some of their experiences with us. All the interviews were conducted in English (except for one individual interview that was conducted in Afrikaans, the home language of both the participant and the researcher) and the participants were all comfortable in expressing themselves in English. A thematic data analysis strategy was employed and the importance of links between government structures, FBOs and family dynamics was undeniable.

\section{The care diamond}

As indicated above, care for minor children is a universal need and used to take place within family or kin structures with additional help from immediate community members. As societies become more layered and complex, other institutions, such as the state (cf. Hochfeld 2007:79f.), take on some responsibility for care towards individuals, but families are usually still regarded as central.

Razavi (2011:879) argues that care should not be relegated to families only and that there is a 'diversity of strategies, institutions and practices for providing care'. In her own work she has developed the concept of a care diamond, which simply draws attention to identifying the state, the family, the NPO sector (or communities) and the market (or private sector) as different institutions involved in caretaking. In the context of the care diamond, the 'market' refers to an individual paying for services, such as private healthcare or childcare. Because this article deals with youth at the margins who are unable to pay for any services, the paid care provided by the market is not relevant in this discussion. The roles of the state, families and FBOs in the South African context will now be considered in more detail whilst linking it with the findings from the study.

\section{The South African state's response to care needs}

In post-apartheid South Africa (after 1994), an elaborate state-supported social assistance grant system was developed, with the Child Care Grant, the Foster Care Grant, the Old Age Grant and the Disability Grant being the main categories. A means test is employed to determine whether an individual qualifies for the grant and, in the case of children, the means test is applied to the child's primary caregiver. In the 2016 General Household Survey it was reported that the 'percentage of individuals that benefited from social grants consistently increased from $12.7 \%$ in 2003 to $29.9 \%$ in 2016 ' and 'the percentage of households that received at least one grant increased from $29.9 \%$ to $44.8 \%$ in 2016' (Statistics South Africa 2017:3). Although the grants are aimed at individuals, they are shared within poor households to make ends meet. The Child Care Grant is less than half of the Foster Care Grant because it is argued that biological parents have financial responsibilities towards their children. Yet, when other kin raise children in the case of death or incapability of the parents, they do not automatically receive the Foster Care Grant, although certain court cases are 
challenging this practice. It has been argued that a new 'kinship grant' should be introduced because there are often willing caretakers available within the extended family, but they may not have the financial means to support children (Reynolds 2016:258).

It is important to note that once young people without disabilities turn 18, they do not qualify for any social assistance grant. Only two of the 24 research participants with whom we had individual interviews and a few of the participants in the one focus group still qualified for the Child Care Grant. Yet six of the participants with whom we had individual interviews had children and two of the female participants were pregnant with their first child at the time of the interviews. The majority of women in the focus group at the shelter had small children. In addition, a few of the research participants still had living grandparents who qualified for the Old Age Grant (about three times the value of the Child Support Grant). Although most of the participants were thus not direct beneficiaries of the social assistance grants at the time of the interviews, some of them may have been indirect beneficiaries. For example, Winnie ${ }^{4}$ was a substance dependent whose 8-year-old child lived with her grandparents and other kin and everybody in that household received a grant.

The high uptake of social assistance grants is not surprising given that unemployment figures are high in South Africa. The official unemployment rate was reported as $26.7 \%$ and the expanded unemployment rate (which includes discouraged people who are not actively seeking employment) as 36.3\% at the end of 2017 (Statistics South Africa 2018a:7). Youth unemployment is particularly high, causing impatience and frustration amongst the youth (Graham \& De Lannoy 2016:s.p.; Naidoo \& Hoque 2017:1-10; Steyn 2015: s.p.). In the General Household Survey of 2016 (Statistics South Africa 2017:12) it was reported that 16.4\% of children between the ages of 7 and 18 years did not attend any educational institution. Not having money for educational fees $(18.7 \%)$ and poor academic performance $(18.9 \%)$ were the main reasons cited for not attending educational facilities. In addition, $18.5 \%$ of females and $1.3 \%$ of males mentioned family commitments as their main reason for not attending and more men cited working as their reason for not being in education.

Work commitments may often be in the informal sector (cf. Statistics South Africa 2018a:1), which 'refers to production and employment in unregistered enterprises' (Meagher 2013:2). The Expanded Public Works Programme and Youth Wage Subsidy (or Employment Incentive Bill) are national initiatives that should assist youth older than 18 years to find employment instead of relying on a social assistance grant, but these programmes are not nearly as widespread or developed as the grant system (cf. Steyn 2015:s.p.). Some of our research participants complained that, although they knew of these opportunities, there was great competition for 4.All names of participants are pseudonyms. it and some questioned the fairness with which it was awarded.

A few of the other strategies to address the needs of the population by the South African state (such as free health services to pregnant women and children under the age of six) may at times overlap with the needs of the youth. However, aspects such as expanding the number of households having access to piped water, sanitation and electricity and building houses (cf. Patel 2014:249) are actually experienced in reverse in areas where urban decay and pollution take over (cf. De Beer 2008:202). Even the more visible tasks associated with government were therefore not always seen to be performed (also the views of some of our research participants). In the focus group with young men and women living in a dilapidated neighbourhood near the city, the verdicts on government performance were harsh: 'Ah that government is a playground!' and 'We are dying, we are dying! By 2020 ah [!] they're going to sell this country, I'm telling you!' Some of these focus group participants described their own neighbourhood as a 'slum area' where ward councillors did nothing for the community and only 'buy cars for themselves'. Because the garbage was piling up in the streets and there were few visible amenities, their negative sentiments were not surprising. Many of the participants in this study stated more specifically that they did not feel the state was doing enough for them as young people:

'No, because I don't even think they [local government] are involved ... I would like for the local government to get involved with us because the way that this organisation is running the programme, it looks like older people [are] not even wanting to get involved with the younger ones.' (Leto, female, 17 years old)

The state's responses to the needs of young people did not seem to reach our research participants in tangible ways and hence many of them expressed negative views on the commitment of government to their plight. The shape of families in South Africa and the experiences of the research participants of this study are considered next.

\section{Family diversity and absent fatherhood}

As mentioned, family diversity and fluidity are ingrained in the South African society with its troubled racial past. Part of the legacy of this troubled past is economic inequality that forms the backdrop for any discussion on family life in South Africa as illustrated above. South African families as we encounter them today should be understood in light of the effects of colonialism, apartheid (with its prolonged system of forced circular migration for black labourers), capitalism and the HIV pandemic (Hall \& Posel 2018:1-20; Rabe 2006:13-57; Reynolds 2016:253-272).

Snapshots of family household configurations in South Africa confirm structural family diversity and multigenerational households are found to be the most common. The General Household Surveys from 2002 to 2012 revealed that 55\% of people lived in extended family households, $36.5 \%$ in nuclear 
family households, $5.3 \%$ in single person households and $3.3 \%$ in complex households (where household members are not related to the household head). Black (67.6\%) and coloured (47.4\%) children (under the age of 18 years) were most likely to live in extended households whilst Indian $(55.8 \%)$ and white $(75.6 \%)$ children were most likely to live in nuclear households (Statistics South Africa 2013:10). The colonial and apartheid histories placed enormous burdens on South African black families because black labourers were often removed from their families as they could not relocate to spaces close to employment. Parents thus often left their children in the care of grandparents or other kin in order to earn money in or near urban areas.

HIV-related illnesses also left many children orphaned, contributing to skip-generation households (grandparents and grandchildren living together) and children (older siblings) raising children. One of the participants in the current study explained his family bonds as follows: 'The three brothers that I have in the house, we support each other, no matter what the problem. Also my sister, we support each other' (Petrus, male, 21 years old). Yet sibling relationships are not always enduring. Peter is an 18-year-old refugee who lost all his family members in fleeing from his home country except for his much older sister. Yet she deserted him shortly after they arrived in South Africa. The fact that extended family members take care of each other should not always be associated with good and loving care (cf. Manderson \& Ellen 2016:212). Although grandparents are often the next of kin to raise children in the absence of parents, it was seen in this research that grandparents may also find it difficult to raise children or they may pass away before their grandchildren are able to look after themselves. Young people in this study were often much worse off after their grandparents died in those cases where their own parents were unknown or deceased.

The striking number of absent biological fathers in family households deserves special mention. The regularly conducted General Household Surveys in South Africa indicated that $61.8 \%$ of children do not live with their biological fathers (the combined percentage of 23\% of children who live with neither biological parent and a further $38.8 \%$ who also do not live with their biological fathers) (Statistics South Africa 2013:ii). Rabe (2016:121-128) highlights various reasons found in the South African literature for this high number of absences. She expounds firstly how the death of biological fathers is not always taken into account when reporting absent fatherhood. For example, $16.2 \%$ of children have a deceased father (12\% paternal orphans and $4.2 \%$ double orphans) (Statistics South Africa 2018b:45). Secondly, many fathers live away from their families due to employment opportunities - a pattern that became commonplace in South Africa due to oscillating migrant patterns that were enforced during the apartheid years on black families. Thirdly, fathers do not always know they have children due to uncertainty of paternity or nondisclosure by maternal families and, lastly, fathers desert their children. An absent biological father does thus not necessarily mean an uncaring father, and furthermore other men may step in to fulfil roles associated with fathers (cf. Rabe 2006:61; Reynolds 2016:263-265). However, despite all these explanations, many men desert their children and lone (or single) motherhood has been clearly linked with a greater likelihood of poverty (Goldblatt 2005:242; Wright et al. 2014:4-51).

Given the statistics on paternal orphanhood, it was not surprising to find in this study of young people at the margins that 13 of the 24 participants' biological fathers had passed away at the time of the interview, some of them when the participants were still very young. In addition, one of the participants did not know whether either of his parents were still alive and a further four participants had been deserted by their fathers. These findings resonate with the general picture of poorer households when biological fathers are absent, and in cases of desertion by a father the findings in this study also resonate with the pain experienced by children who are deserted by their biological fathers (cf. Lobaka 2018:59). For example, Maria, a 17-year-old participant in Grade 11 who lived with her mother and her two siblings at the time of the interview, reported that her father lived in Johannesburg and that she had not seen him for a long time. She simply said: 'No, he doesn't talk with us', started crying and then repeated: 'He doesn't talk with us anymore'. She managed to convey that they survived financially because her mother worked very hard, but we ended the interview in order not to upset her further. In other cases participants had simply nothing to say about their biological fathers because they did not know them and in other instances there were irreparable relationships such as Mpho (female, 22 years old), who did not want to return home and described her father as 'an angry person'.

Apart from our research participants growing up without fathers being present in their lives, certain research participants also had children themselves who grew up without fathers, thus repeating the cycle of absent fathers. Winnie, for example, had an 8-year-old daughter and she revealed:

'No, the time I got pregnant I didn't know actually who the father was. Because that time I was dating two guys, I was still young, I was maybe 15 years old, so I was confused by the situation. So, I didn't tell either of the guys.' (Winnie, female, 24 years old)

Undisclosed fatherhood is preventing fathers from knowing their children, and cases such as that of Winnie's daughter (who in future will be unlikely to locate her biological father) reveal a likely repetition of such patterns.

A number of qualitative studies in South Africa underscore the expectation that fathers should provide financially for their children and the lack of self-worth they experience if they are unable to do so (cf. Rabe 2016:127-128). Similarly in this study, Luke (male, 21 years old) expressed his belief regarding his financial responsibilities towards his family members repeatedly, although he was unable to meet these 
expectations. When Luke was 2 years old, his father was killed in a taxi violence incident in KwaZulu-Natal Province, and his mother had deserted him and his brother prior to this incident. His stepmother did not want to take care of them and his paternal aunt raised them with her own two children. After finishing school he came to Pretoria to study, but after completing the first semester, he wanted to find a job to supplement his funds so that he could dress better and fit in with the materialistic youth culture on campus. He could not find a job and he missed registering for the second semester for various reasons. He mostly lived on the streets, although he often slept at a friend's house. He did not have the funds to return to KwaZulu-Natal and he also felt too ashamed to face his aunt, towards whom he felt an enormous responsibility:

'Because now I can't just ask for money at home because my aunt she is telling me 'no the money I can give you is specifically the money that you can use to travel back home. You understand?' So eish, so I don't want to run from that because she supported me. And I don't want her to lose that trust in me because ... because when I was young the people they did not want to volunteer to raise me, she was the only one in my family.' (Luke, male, 21 years old)

Luke's girlfriend became pregnant whilst still in school and the baby was born in her final year of school. He thought that she performed worse than expected because of all the school she missed with the birth of the baby and hence also the opportunity to study further - a general pattern where girls are more adversely affected by teenage pregnancy than boys (Shefer \& Fouten 2012:149-168). He felt regret and guilt about this and therefore wanted to find a good job to support her and the 1-year-old child as well (he had seen the child only twice). He regarded money as a good way to compensate for other hardships:

'I want her to have money so that if I can go there, home, and want to know I have money to get them things, buying them clothes, make them feel ... show what love is. You see it is easy to show love if you have money, but if you don't have money it is hard to show love.' (Luke, male, 21 years old)

Luke was offered a gun by an acquaintance and invited to take part in an armed robbery. He resisted this with difficulty and he insisted that the main reason was that he was not actually hungry due to FBOs providing food at various places in the city.

Luke's deliberations show how the absence of parents, for whatever reason, results in other family members having to take care of children, often under very difficult circumstances. Young men such as Luke, who want to step up and support family members in a highly materialistic environment, find it difficult to do without specialised skills or advanced education.

\section{Fluid family structures in lived experiences}

In addition to the static percentages gleaned from censuses and cross-sectional surveys in South Africa, the fluidity of family households was brought into sharp focus in the 1990s by a number of anthropological studies that provided close-up pictures of how family members moved between households as strategies of survival but also to take advantage of educational and income-generating activities (cf. Spiegel 1996:5-6). The National Income Dynamics Study is a representative panel study ${ }^{5}$ in South Africa that has provided quantitative data on households since 2008, hence broadening the picture of fluidity provided by closeup studies. Grieger et al.'s (2014:151) analysis of the first two waves of the data $(2008,2010$ and 2011) revealed that short-term residential change was unexceptional in South Africa, with $10.5 \%$ of South Africans changing residence between 2008 and 2010. Differently stated, 1 in 10 South Africans moved to a new household in a 2-year period, but more astoundingly $61.3 \%$ of South Africans changed household composition between 2008 and 2010. Family members thus moved between households regularly, confirming the fluidity of family life in South Africa. The strategies of mobility and circular migration are well known and there is continued interest in how the mobility of young people contributes to such survival strategies (Hall \& Posel 2018:1).

There were also men in our study who contributed financially to their families by mobilising limited resources as best as possible by moving between households. Tshepo, for example, was an informal worker who washed cars and lived on the street. He had not completed his high school education because of financial constraints. He had a 3-yearold child at the time of the interview and he believed he also had economic responsibilities towards his younger sister, who was still at school and living with their uncle. His parents had passed away a few years ago and his girlfriend and his sister lived in Ga-Rankuwa (about 40 kilometres away from the central part of the city where Tshepo lived). He explained:

'Yes, but I am also budgeting like Monday, Tuesday, Wednesday, Thursday, Friday at least it's R100 [income per day], then it will be R500 [per week]. Saturday, I take R250 to my young sister and then Sunday I take R200 to my girlfriend. The other week I am doing for myself and the other week, I go and visit and I give them money again. The one week is mine and the other week is for them, and the one week is mine and the other week is for them.' (Tshepo, male, 25 years old)

With this schedule, Tshepo was able to give financial support to his dependents even though he had precarious living and working conditions. He was thus fulfilling the role of economic provider - a role that is seen as paramount in many sectors of the South African society even though he is a nonresident father (cf. Morrell 2006:13-25; Rabe 2016:120-128).

Despite the best efforts of individuals such as Tshepo, there is a general picture of family and state failure in care. This can be described as a care deficit, which many of our research participants experienced. In the next section, the ways in

5.A panel study follows the same sample of participants over a number of years in order to track changes in their lives over time. 
which FBOs assist in the care of youth at the margins in the City of Tshwane is further discussed.

\section{Faith-based organisations as sources of support}

Religious bodies (such as churches) have a long history of philanthropic work in South Africa (Burchardt 2013:628; Hochfeld 2007:79). The difference between a church and an FBO is not always clear-cut, especially in the case of urban ministry. Researchers focusing on inner cities in South Africa are generally clear on the distinction between churches and FBOs, as can be seen in the work of Van Wyngaard (2017:3), who defines church as the 'local worshipping community' or 'church assembled'. It does not mean that the broader social structures of churches are ignored or that responses derived from faith to other people's needs are ignored, but it is not the main focus of the topic. Similarly to such researchers, participants in our study who attended church services and related activities regularly often regarded these bodies as providing spaces for like-minded people to meet and express their faith in various ways, for example: 'Because it's [the church] inviting and when the pastor speaks, you feel like he is speaking directly to you' (Petrus, male 21 years old). Certain participants, such as Petrus, were clear on the role of the church only being related to matters of faith whilst others had mainly instrumental approaches to the church:

'I like [the church] because also sometimes they gave us water to bathe, you see? And then they give us like a lock to keep your clothes safe, you see? Ja, and then tea, they give us like in this one, they sell the tea now here, like R2 coffee. $^{\prime 6}$ (Lucky, male, 21 years old)

'It's a church where I eventually go to every Sunday and they're helping me out with things, maybe let's say with blankets and clothes, but not the church basically, the people in the church, and there's a guy that's also working there doing sound engineering and he offered me to come and join the worship team to come and do sound engineering, because he does it, practise with them and everything.' (Calvin, male, 25 years old)

In other cases, there is a blurring between aspects related to faith, worship and even social activities and instrumental aspects of churches:

'There's normally Sunday school and then we have a women's choir on Wednesdays and Saturdays and then during the week you just go there, sit there and if you study, study there.' (Leto, female, 17 years old)

In this regard, the typology on urban ministry provided by Franklin (2002:xii) complicates the distinction between churches and FBOs. The author places churches on a continuum in terms of the different levels of organisation and structure they exhibit in providing practical support to people in need. Franklin (2002:xii) identifies five types of ministries, with the first being a 'ministry of charity and mercy' that responds to the immediate physical needs of people by providing things such as clothes and food parcels. The second and third areas are referred to as a 'ministry of nurture' and 'human service', respectively, which aspires to help people in a more comprehensive manner by helping them become self-reliant. Where the former may assist people to find employment, the latter may actually provide job training. The fourth area is described as a 'ministry of justice' that will focus on members of society who are marginalised, especially where government structures failed. The final area is termed a 'ministry of comprehensive community transformation'. In this case, churches try to take a prominent role in establishing a 'good' community or city. The latter three types of ministries can in many ways be equated with an FBO.

The question is why FBOs have become a prominent manifestation of religious-based organisations in recent times in addition to churches. Burchardt (2013:628) answers this question by defining an FBO as 'a voluntary non-profit organisation, based on the principles of a particular faith, working towards collective goods, embedded in civil society, and modelled along the lines of its secular sibling, the NGO'. In South Africa, FBOs are categorised under the larger nonprofit sector (NPOs), which is supported by the Non-Profit Organisations Act (No. 71 of 1997). Many NPOs register with the South African government because in doing so they gain benefits from the state as well as a certain level of legitimacy that may attract donors more easily (Patel 2014:250). Patel (2014:250-253) divides NPOs into four main categories, namely formal public service contractors, donor-funded organisations, FBOs (mainly funded by religious bodies) and community-based organisations. According to a survey released in 2002 quoted by Patel, 11\% of NPOs in South Africa have links with religious organisations. A number of FBOs operate in the City of Tshwane (cf. De Beer 2008:201-206).

Burchardt (2013:628-629) argues that FBOs can either be analysed as organisations with an emphasis on the structural aspects, or they can be regarded as 'expressions of faith' that include reasons to participate in the first place and practices and discourses that link involved parties. In this particular fieldwork, the formal FBOs through whom we sampled our participants were regarded by the participants either as an instrumental body or they were unaware of their existence (especially if they had not been living in the city for long). Because the focus in this article is on the structural aspects of FBOs, ${ }^{7}$ the links between the state, families and FBOs are illustrated next through drawing more pertinently from our research.

A clear example of how a breakdown in family support has been handled by state institutions and a FBO is the case of Thabeo ( 23 years old). At the time of the interview she was eight and a half months pregnant and living in a house of safety provided by an FBO. Her biological father had passed away when she was 11 years old and a year later her younger sister died, leaving only her and her mother. Her mother never remarried, but she left for Ghana to work as a pastor when Thabeo was 21 years old. Thabeo was studying towards 7.See De Beer (2008) for a considerate interpretation of FBOs as expressions of faith. 
a diploma and lived with her boyfriend. However, when she told him that she was pregnant, he wanted her to abort the baby or leave their apartment. She refused an abortion and had to make alternative living arrangements. Although she tried to make contact with other family members, she found herself on the street one night sleeping under a bridge with other homeless people. Her tablet, mobile phone and other belongings were stolen that night and she could hear 'other women crying, screaming you know, like someone was forcing them to do something that they don't want'. She went to the police station the following morning with the help of another woman; they contacted a social worker who had ties with a place of safety provided by a local FBO. As a result of the combined efforts of state departments and the FBO, she had reconnected with family members at the time of the interview and would join them after the birth of her child. At the time of the interview she was staying in a shelter for women run by this particular FBO. This is thus a good example of synergy between the local government structures (including the police department), a dedicated FBO and extended family members. Unfortunately, it appears as if such cases are rare.

The fluid family structure with multiple moves between different households are common in South Africa, as already described. A new aspect raised in this research was how this fluidity between family households is sometimes extended to FBOs, as vividly illustrated by Josephine's narrative. Josephine (21 years old) never met her father but when she was approximately 14 years old, somebody told her that he had passed away. She had been living in a foster care home provided by a FBO since the age of 12 years as her mother could not provide for her and her brother any longer. Her younger brother did not cope well in a shelter for boys and her mother eventually fetched him to live with her again. This made Josephine very sad but her mother explained the adverse economic situation they found themselves in and Josephine accepted it and apparently made use of all possible opportunities. She completed her schooling when she was 18 years old (the expected age if there is no interruption in schooling). At the time of the interview she was 21 years old and volunteering in a government programme whilst continuing with studies on a part-time basis.

\section{Conclusion}

Although the findings from this research are by no means representative of youth in Pretoria Central due to the qualitative nature and purposive sampling of the participants, the contemporary knowledge on South African families resonates here. The statistical portrayals of family life can be seen close up when fathers are absent and mothers and grandparents struggle to raise children (the biological parents of only 1 of the 24 participants lived together as a couple). Once these children from mostly poor families become adults, the daily struggle for survival continues and the cycle carries on, but often without the support from older generations because they are either deceased or estranged from them. Even though some young men have limited access to economic opportunities, they still experience the weight of expectations that they should be providers. Both informal work and crime are possible avenues of income for such men, albeit both insecure in nature. Moreover, in our case study the strategy of individual family members moving between households often continued as a survival strategy for young adults who lived in Pretoria Central, but they were moving between being homeless (sleeping on the street), living in shelters and back with family households. Faithbased organisations offering temporary living quarters and other resources thus became part of the survival options for some urban young people at the margins and effectively filled the void that extended kin structures may have filled in the past. Unfortunately, these positive forms of support appeared to be limited and not available to the majority of marginalised youth.

Many young people experience a care deficit where their family members desert them, are deceased or simply unable to help them further. The state structures are clearly not supporting young people in a comprehensive manner and hence certain FBOs fill a void. However, given the magnitude of need experienced by young people (e.g. the high unemployment levels), FBOs require much more support from the state, whose resources do not reach all young people.

\section{Acknowledgements}

The author wishes to acknowledge the support of Prof. Ignatius Swart as the grant holder of the project and coresearcher of this case study as well as Dr Stephan de Beer, co-researcher of this case study.

\section{Competing interests}

The author declares that she has no financial or personal relationships which may have inappropriately influenced her in writing this article.

\section{References}

Budlender, D. \& Lund, F., 2011, 'South Africa: A legacy of family disruption', Development and Change 42(4), 925-946.

Burchardt, M., 2013, "We are saving the township": Pentecostalism, faith-based organisations, and development in South Africa', Journal of Modern African Studies 51(4), 627-651.

De Beer, S., 2008, 'Contesting inner-city space: Global trends, local exclusion/s and an alternative Christian spatial' Missionalia 36(2/3), 181-207.

Department of Social Development, Republic of South Africa, 2012, Draft White Paper of Families in South Africa, The Department of Social Development, Pretoria.

Franklin, R.M., 2002, 'Preface', in E. Villafane, B.W. Jackson, R.A. Evans \& A.F. Evans (eds.), Transforming the city. Reframing education for urban ministry, pp. xi-xvi, William B. Eerdmans, Grand Rapids, MI.

Goldblatt, B., 2005, 'Gender and social assistance in the first decade of democracy: A case study of South Africa's Child Support Grant' Politikon: South African Journal of Political Studies 32(2), 239-257.

Graham, L. \& De Lannoy, A., 2016, Youth unemployment: What can we do in the short run? Econ3X3, Cape Town.

Grieger, L., Williamson, A., Leibbrandt, M. \& Levinsohn, J., 2014, 'Evidence of short term household change in South Africa from the National Income Dynamics Study', Development Southern Africa 31(1), 146-167.

Hall, K. \& Posel, D., 2018, Fragmenting the family? The complexity of household migration strategies in post-apartheid South Africa, United Nations University World Institute for Development Economics Research.

Hochfeld, T., 2007, 'Missed opportunities: Conservative discourses in the draft National Family Policy of South Africa', International Social Work 50(1), 79-91. 
Lobaka, S.T., 2018, 'Exploring the experiences of young adult women growing up with non-resident fathers in North West - Tlokwe Local Municipality', MA thesis, University of South Africa.

Makiwane, M., Gumede, N.A. \& Molefi, S., 2016, 'Continuity and change: Relationships, childbearing and children's living arrangements', in M. Makiwane, M. Nduna \& N.E. Khalema (eds.), Children in South African families, pp. 24-40, Cambridge N.E. Khalema (eds.), Children in South
Scholars Publishing, Newcastle upon Tyne.

Manderson, L. \& Ellen, B., 2016, 'Relatedness and care in Southern Africa and beyond', Social Dynamics 42(2), 205-217.

Meagher, K., 2013, Unlocking the informal economy: A literature review on linkages between formal and informal economies in developing countries, Manchester, Wiego Working Paper No 27.

Morrell, R., 2006, 'Fathers, fatherhood and masculinity in South Africa', in L. Richter \& R. Morrell (eds.), Baba. Men and Fatherhood in South Africa, pp. 13-25, Human Sciences Research Council, Cape Town.

Mosoetsa, S., 2011, Eating from One Pot. The dynamics of survival in poor South African households, Wits University Press, Johannesburg.

Naidoo, M. \& Hoque, M.E., 2017, 'Reducing youth unemployment beyond the Youth Wage Subsidy: A study of Simtech apprentices', SA Journal of Human Resource Management 1, 1-10.

Patel, L., 2014, 'Gender and care in the non-profit sector in South Africa: Implications for welfare policy', In V. Reddy, S. Meyer, T. Shefer \& T. Meyiwa (eds.), Care in context. Transnational gender perspectives, pp. 246-264, HSRC Press, Cape Town

Rabe, M., 2006, 'Black mineworkers' conceptualisations of fatherhood. A sociological exploration in the South African goldmine industry', PhD Thesis, Univeristy of South Africa, Pretoria.

Rabe, M., 2016, 'Revisiting the gendered discourse on parenting in South Africa', in M. Makiwane, M. Nduna \& N.E. Khalema (eds.), Children in South African families. lives and times, pp. 116-138, Cambridge Scholars Publishing, Newcastle upon Tyne.
Rabe, M., 2017, 'Family policy for all South African Families', International Social Work 60(5), 1189-1200.

Razavi, S., 2011, 'Rethinking care in a development context', Development and Change 42(4), 873-903.

Reynolds, L., 2016, 'Deciphering the "duty of support": Caring for young people in KwaZulu-Natal, South Africa', Social Dynamics 42(2), 253-272.

Shefer, T. \& Fouten, E., 2012, 'Being a young parent: The gendered sharing of care work', in R. Morrell, D. Bhana \& T. Shefer (eds.), Books and babies. Pregnancy and young parents at school, pp. 149-168, HSRC Press, Cape Town.

Spiegel, A., 1996, 'Introduction: Domestic fluidity in South Africa', Social Dynamics 22(1), 5-6.

Statistics South Africa, 2013, Social profile of vulnerable groups 2002-2012, StatsSA, Pretoria.

Statistics South Africa, 2017, General Household Survey 2016 P0318, StatsSA, Pretoria.

Statistics South Africa, 2018a, Quarterly Labour Force Survey. Quarter 4:2017, StatsSA, Pretoria.

Statistics South Africa, 2018b, Men, women and children: Findings of the living conditions survey 2014/2015, StatsSA, Pretoria.

Steyn, L., 2015, 'Analysts split over wage subsidy', Mail \& Guardian, 27 November, viewed 12 January 2018, from https://mg.co.za/article/2015-11-27-00-analystssplit-over-wage-subsidy

Swart, I., 2013, 'Youth at the margins: Introducing a new research initiative in an ongoing south-north collaboration in the context of international diaconia', Diaconia 4(1), 2-26.

Van Wyngaard, G.J., 2017, 'Conceptual considerations for studying churches' engagement with urban fractures and vulnerabilities', HTS Teologiese Studies/ Theological Studies 73(3), 1-7.

Wright, G., Noble, M. \& Ntshongwana, P., 2014, The impact of poverty and inequality on the dignity of lone mothers in South Africa, ESRC \& DFID, The Centre for the Analysis of South African Policy. 